\title{
Zinc and the immune system
}

\author{
Lothar Rink* and Philip Gabriel \\ Institute of Immunology and Transfusion Medicine, University of Lübeck School of Medicine, Ratzeburger Allee 160, \\ D-23538 Lübeck, Germany
}

\begin{abstract}
$\mathrm{Zn}$ is an essential trace element for all organisms. In human subjects body growth and development is strictly dependent on $\mathrm{Zn}$. The nervous, reproductive and immune systems are particularly influenced by $\mathrm{Zn}$ deficiency, as well as by increased levels of $\mathrm{Zn}$. The relationship between $\mathrm{Zn}$ and the immune system is complex, since there are four different types of influence associated with $\mathrm{Zn}$. (1) The dietary intake and the resorption of $\mathrm{Zn}$ depends on the composition of the diet and also on age and disease status. (2) $\mathrm{Zn}$ is a cofactor in more than 300 enzymes influencing various organ functions having a secondary effect on the immune system. (3) Direct effects of $\mathrm{Zn}$ on the production, maturation and function of leucocytes. (4) $\mathrm{Zn}$ influences the function of immunostimulants used in the experimental systems. Here we summarize all four types of influence on the immune function. Nutritional aspects of $\mathrm{Zn}$, the physiology of $\mathrm{Zn}$, the influence of $\mathrm{Zn}$ on enzymes and cellular functions, direct effects of $\mathrm{Zn}$ on leucocytes at the cellular and molecular level, $\mathrm{Zn}$-altered function of immunostimulants and the therapeutic use of $\mathrm{Zn}$ will be discussed in detail.
\end{abstract}

\section{Zinc: Immune system}

Raulin (1869) showed that $\mathrm{Zn}$ is essential for the growth of Aspergillus niger. Todd et al. (1934) were the first to show that $\mathrm{Zn}$ is necessary for the growth and development of rats. Approximately 100 years after the initial observation by Raulin, Prasad et al. (1963) described a Zn-deficiency syndrome in children from Persia practising geophagia. The syndrome was characterized by anaemia, hypogonadism, hepatosplenomegalie, skin alterations and growth and mental retardation. The discovery of acrodermatitis enteropathica (a rare autosomal recessive inheritable disease) as a Zn-specific malabsorption syndrome (Neldner \& Hambidge, 1975) indicated clearly that these symptoms are related to $\mathrm{Zn}$ deficiency. This disease is also accompanied by thymic atrophy resulting in an immune defect and a high frequency of bacterial, viral and fungal infections. Without treatment this disease leads to death within a few years, but pharmacological $\mathrm{Zn}$ supplementation can reverse all symptoms (Neldner \& Hambidge, 1975).

\section{Nutritional aspects and physiology of zinc}

The total body $\mathrm{Zn}$ content of human subjects is $2-4 \mathrm{~g}$. However, $\mathrm{Zn}$ is referred to as a trace element, as its plasma concentration is only $12-16 \mu \mathrm{M}$. In the serum, $\mathrm{Zn}$ is predominantly bound to albumin (60\%, low-affinity), $\alpha_{2}$ macroglobulin (30\%, high-affinity) and transferrin (10\%; Scott \& Bradwell, 1983). The plasma $\mathrm{Zn}$ pool is a minor pool, but highly mobile and immunologically important. There is no specialized Zn storage system in the body, and therefore there must be a daily intake of $\mathrm{Zn}$ to achieve a steady-state. The distribution of $\mathrm{Zn}$ in the body is summarized in Table 1 (Mills, 1989; Favier \& Favier, 1990).

The bioavailability of $\mathrm{Zn}$ depends on the composition of the diet. $\mathrm{Zn}$ is chelated by phytate and phosphate, resulting

Table 1. Zinc content of human organs

\begin{tabular}{lcc}
\hline & \multicolumn{2}{c}{ Zn content } \\
\cline { 2 - 3 } Organ & $\mu \mathrm{g} / \mathrm{g}$ organ dry wt & \% whole-body $\mathrm{Zn}$ \\
\hline Muscle & 51 & $57 \cdot 0$ \\
Bone & 100 & $29 \cdot 0$ \\
Skin & 32 & $6 \cdot 0$ \\
Liver & 58 & $5 \cdot 0$ \\
Brain & 11 & 1.5 \\
Kidneys & 55 & $0 \cdot 7$ \\
Heart & 23 & $0 \cdot 4$ \\
Hair & 150 & $0 \cdot 1$ \\
Plasma & 1 & $0 \cdot 1$ \\
\end{tabular}

Abbreviations: IFN, interferon; IL, interleukin; LPS, lipopolysaccharide; MHC, major histocompatibility complex; PBMC, peripheral blood mononuclear cells; PHA, phytohaemagglutinin; PKC, protein kinase C.

*Corresponding author: Dr Lothar Rink, fax +49 451500 3069, email rink@immu.mu-luebeck.de 
in a poor resorption from vegetarian food in comparison with meat. Furthermore, the resorption is reduced by increased levels of other bivalent cations, such as $\mathrm{Cu}, \mathrm{Mg}$, $\mathrm{Ca}, \mathrm{Ni}, \mathrm{Cd}$ and Fe (Valberg et al. 1984; Favier \& Favier, 1990). Fe is of special interest, as most pregnant women take Fe supplements, and some studies have shown a correlation between abortion or preterm delivery and $\mathrm{Zn}$ deficiency (Mills, 1989; Favier \& Favier, 1990; Scholl et al. 1993). Thus, interaction between supplements must be taken into account when a single supplement is taken. The $\mathrm{Zn}$ content of food also shows a wide variation (Table 2; Favier \& Favier, 1990). A balanced diet is therefore important for an adaquate $\mathrm{Zn}$ uptake. Variations in the bioavailability of $\mathrm{Zn}$ and $\mathrm{Zn}$ content make the $\mathrm{Zn}$ intake from food difficult to calculate. Health status and age are also important factors in the daily $\mathrm{Zn}$ intake. During the growth period, pregnancy and nursing there is an increased requirement for $\mathrm{Zn}$, since $\mathrm{Zn}$ is essential for every proliferating cell, and the daily loss by excretion is approximately the same as the daily intake (Table 3; Ziegler et al. 1989; German Society of Nutrition, 1995). $\mathrm{Zn}$ absorption depends on the concentration in the diet and is about 20-40\% of the daily intake (Mills, 1989). However, there are a number of contradictory recommendations relating to the daily intake of $\mathrm{Zn}$.

The daily intake must be adjusted according to health status, since Zn steady-state is regulated not only by uptake, but also by fluctuations in $\mathrm{Zn}$ excretion associated with a number of diseases and with inflammation (Klaiman et al. 1981; Yuzbasiyan-Gurkan et al. 1989; Weiss et al. 1998). Interestingly, healthy elderly subjects have decreased serum

Table 2. Zinc content of some foods (mg/100g)

\begin{tabular}{lclc}
\hline \multicolumn{2}{l}{ Meat and animal products } & \multicolumn{2}{l}{ Vegetables and plant products } \\
\hline Beef fillet & $3 \cdot 6$ & Wheat (white) flour & 0.9 \\
Liver & $4-6$ & Wholemeal flour & 3.0 \\
Roast beef & 2.5 & Sugar & 0.1 \\
Pork fillet & $3 \cdot 6$ & Potato & $0.2-0.3$ \\
Pork cutlet & 1.3 & Carrot & 0.64 \\
Pork shoulder & $3 \cdot 5$ & Radish & $0 \cdot 16$ \\
Calf fillet & $4 \cdot 3$ & Cauliflower & 0.23 \\
Poultry & $2-3$ & Salad & 0.22 \\
Fish & $1-2$ & Red cabbage & 0.22 \\
Oysters & $20-150$ & Sauerkraut & 0.32 \\
Eggs & $0.3-0.5$ & Fruit & $0.1-0.3$ \\
Milk & $0 \cdot 2-0.4$ & Vegetable oil & $0.1-0.2$ \\
Cheese & $1-5$ & Sweetcorn & 1.2 \\
Butter & 0.15 & Coconut & 0.5 \\
& & Rice & 1.3
\end{tabular}

Table 3. Recommended daily intake of zinc (mg/d; German Society of Nutrition, 1995)

\begin{tabular}{llr}
\hline Infants and children: & $0-<12$ months & 5 \\
& $1-<4$ years & 7 \\
$4-<7$ years & 10 \\
$7-<10$ years & 11 \\
& $10-<13$ years & 12 \\
Adolescents and adults: & Male & 15 \\
& Female & 12 \\
& Pregnant & 15 \\
& Nursing women & 22 \\
\hline
\end{tabular}

Zn levels, which may be due to decreased resorption or increased excretion (Cakman et al. 1996). Acute infections lead to a redistribution of $\mathrm{Zn}$ to the liver, decreasing the immunologically-important serum pool (Weiss et al. 1995).

All these factors may result in an immune deficiency, but there are no specific immunological defects, only inappropriate or inadequate nutrition. However, long-term $\mathrm{Zn}$ deficiency due to inappropriate nutrition may result in immunological or autoimmune diseases.

\section{Cell biology of zinc}

Exogenous $\mathrm{Zn}$ enters the cell within minutes (Wellinghausen et al. 1996b). However, it is not known how $\mathrm{Zn}$ enters the cell. Some specific $\mathrm{Zn}$ transporters have been reported in the nervous system, but these transporters inhibit the efflux of the intracellular $\mathrm{Zn}$ pool and some have been reported to be involved in intracellular redistribution, but there is no evidence that these transporters are involved in Zn uptake (Palmiter \& Findley, 1995; Palmiter et al. 1996a,b; Tsuda et al. 1997). The transferrin receptor (CD71) has been reported to promote $\mathrm{Zn}$ influx, as for $\mathrm{Fe}$, but this finding has not been confirmed by other workers (Wellinghausen et al. 1996b). Thus, there are no irrefutable data to indicate that $\mathrm{CD} 71$ is a $\mathrm{Zn}$ receptor. Different possible mechanisms for $\mathrm{Zn}$ uptake such as non-specific $\mathrm{Ca}$ channels, facilitated diffusion via amino acids and anionic exchange have been reported (Bentley, 1992; Hogstrand et al. 1996). In peripheral blood mononuclear cells (PBMC) exogenously-added $\mathrm{Zn}$ increases the free $\mathrm{Zn}$ content by about $70 \%$ (Wellinghausen et al. 1996b), whereas the total $\mathrm{Zn}$ uptake is $300-600 \%$, indicating rapid binding of $\mathrm{Zn}$ to intracellular proteins (A Fischer, P Gabriel and L Rink, unpublished results).

$\mathrm{Zn}$ is a cofactor for more than 300 enzymes (Coleman, $1992 a, b$; Vallee \& Falchuk, 1993). In some enzymes $\mathrm{Zn}$ is important for structural integrity, whereas in other enzymes it is the central ion for enzymic activity, but sometimes both these functions are involved, as in alcohol dehydrogenase. As a third possibility, $\mathrm{Zn}$ modulates the activity of a number of enzymes. Members of all six classes of enzymes use $\mathrm{Zn}$ as a cofactor (Table 4). A variety of general cell functions are therefore influenced by the $\mathrm{Zn}$ concentration. Factors interacting with DNA and RNA (e.g. transcription and replication factors), particularly, are $\mathrm{Zn}$-dependent, because their structure shows a Zn-finger motif (Table 5). As a result cell proliferation does not occur in the absence of $\mathrm{Zn}$,

Table 1. Enzymes with zinc as a co-factor (examples in each enzyme class)

\begin{tabular}{|c|c|c|}
\hline Enzyme & $\begin{array}{l}\text { No. of } \mathrm{Zn} \text { ions and their } \\
\text { function }\end{array}$ & Enzyme class \\
\hline Alcohol dehydrogenase & $\begin{array}{l}\text { One for stability and one } \\
\text { for enzyme activity }\end{array}$ & Oxidoreductase \\
\hline RNA polymerase & Two for catalytic activity & Transferase \\
\hline Alkaline phosphatase & $\begin{array}{l}\text { Two for catalytic activity } \\
\text { and co-activity }\end{array}$ & Hydrolase \\
\hline Carbonic anhydrase & One for catalytic activity & Lyase \\
\hline Aldolase II (fungi) & One for catalytic activity & Isomerase \\
\hline t-RNA synthetase & $\begin{array}{l}\text { One or two for catalytic } \\
\text { activity }\end{array}$ & Ligase \\
\hline
\end{tabular}


Table 5. Some proteins containing zinc-finger motifs

\begin{tabular}{lll}
\hline Molecule containing Zn-fingers & Function & Reference \\
\hline Oestradiol receptor & Hormone receptor & Humeny et al. (1999) \\
Glucocorticoid receptor & Hormone receptor & Schoenmakers et al. (1999) \\
AIRE-protein & Gene product, probably responsible for autoimmune & The Finnish-German APECED Consortium \\
& polyendocrinopathy-candidiasis-ectodermal dystrophy & (1997) \\
MTB-Zf & MTB-Zf expression leads to the haem-oxygenase-1 gene product & Muraosa et al. (1996) \\
Myelin transcription factor 1 & DNA-binding protein, important for oligodendrocyte development & Armstrong et al. (1995) \\
ZNF7 & Lack of this protein expression in Burkitt lymphomas & Feduchi et al. (1994) \\
Z-225 (Egr-1) & Upregulation in RA synoviocytes & Aicher et al. (1994), Aicher et al. (1999) \\
WT-1 & Expression in myeloid leucaemia and Wilms tumour & Deuel et al. (1999) \\
TFIIIA & Transcription factor & Pavletich \& Pabo (1993) \\
TIEG & Transcription factor & Chalaux et al. (1999) \\
EGR3/Pilot & Transcription factor & Yamagata et al. (1994) \\
RFLAT-1 & Transcription factor & Song et al. (1999) \\
mSNA & Transcription factor & Nakayama et al. (1998) \\
YY1 & Transcription factor & De-Rinaldis et al. (1998) \\
REST & Transcription factor & Andres et al. (1999) \\
AREB6 & Transcription factor & Turner \& Crossley (1998) \\
Gli-1 & Transcription factor & Hynes et al. (1997) \\
GATA-6 & Transcription factor & Sakai et al. (1998) \\
WZF-1 & Transcription factor & Skamoto et al. (1996) \\
RU 49 & Transcription factor & Yang et al. (1996) \\
SP 1 & Transcription factor & Philipsen \& Suske (1999) \\
BCL 6-protein & Transcription repressor & Chang et al. (1996) \\
ZNF174 & Transcription repressor & Williams et al. (1995) \\
\hline RA & &
\end{tabular}

$\mathrm{RA}$, rheumatoid arthritis.

and highly-proliferating cell systems, such as the immune system, the skin and the reproductive system, are the most sensitive indicators of $\mathrm{Zn}$ deficiency. Furthermore, different factors important for signal transduction need $\mathrm{Zn}$ to maintain their normal function; thus, $\mathrm{Zn}$ can alter their function, but this change does not necessarily involve a loss of function (Maret et al. 1999). Enzymes inhibited by $\mathrm{Zn}$ include: caspase-3, fructose-1,6-bisphosphatase, glyceraldehyde-3-phosphase dehydrogenase, aldehyde dehydrogenase, tyrosine phosphatase, enolase. Also, the translocation of protein kinase $\mathrm{C}(\mathrm{PKC})$ to the cell membrane is $\mathrm{Zn}$ dependent.

More recently, Taylor \& Blackshear (1995) reported that $\mathrm{Zn}$ influences the stability of mRNA by inhibiting its turnover. The resultant accumulation of mRNA is assumed to regulate gene expression, and might therefore also play a role in $\mathrm{Zn}$-induced effects.

Apoptosis represents a physiological method of cell death. Without apoptosis development is not maintained, the exclusion of autoimmune T-cells and B-cells is lost and the killing activity of cytotoxic T-cells and NK cells decreases. Apoptosis is regulated by $\mathrm{Zn}$ and $\mathrm{Zn}$ chelation in the culture medium causes apoptosis (Jiang et al. 1995; Umezawa et al. 1999). On the other hand, the addition of $\mathrm{Zn}$ can protect cells against undergoing apoptosis. This protective action has been reported in relation to almost all apoptosisinducing factors, including tumour necrosis factor- $\alpha$, cytotoxic T-cells, dexamethasone, withdrawal of interleukin (IL) 2 (in IL-2-dependent T-cell lines), sporidesmin, cold shock, etoposide, hyperthermia, adenosine, and u.v. and $\gamma$-irradiation (Zalewski \& Forbes, 1993). Interestingly, Zn can inhibit apoptosis even if added a short time after the apoptotic agent. Possible mechanisms for this anti-apoptotic effect are the inhibition of caspase-3, a direct interaction with bcl-2, or an induction of DNA synthesis by $\mathrm{Zn}$ (Fukamachi et al. 1998; Ishido et al. 1999; Maret et al. 1999). Other anti-apoptotic mechanisms suggested for $\mathrm{Zn}$, are $\mathrm{Ca}$ antagonism, inhibition of the $\mathrm{Ca}^{2+} / \mathrm{Mg}^{2+}$ endonuclease and an interaction between $\mathrm{Zn}$-finger proteins and the microtubuli system (Zalewski \& Forbes, 1993). It is possible that $\mathrm{Zn}$ has various independent anti-apoptotic effects and that cell activation alone can prevent apoptosis. During the early stages of apoptosis there is a major redistribution of intracellular $\mathrm{Zn}$. The increase in free $\mathrm{Zn}$ in the cytosol is a result of $\mathrm{Zn}$ release from intracellular pools and metalloenzymes (Maret, 1998).

All these effects of $\mathrm{Zn}$ are very important for the highly-proliferative and physiologically-active leucocytes, but they are not restricted to the cells of the immune system. However, a slightly decreased $\mathrm{Zn}$ status might be associated initially with immunological effects, in the form of an increased number of infections.

\section{Specific interactions of zinc within the immune system}

It has been established that $\mathrm{Zn}$ is an essential trace element for the immune system. However, the cellular and molecular mechanisms for the role of $\mathrm{Zn}$ within the immune system have been elucidated only during the last 10 years.

The innate as well as the specific parts of the immune system are influenced by $\mathrm{Zn}$. The effects of $\mathrm{Zn}$ are multifaceted. $\mathrm{Zn}$ can induce adhesion of myelomonocytic cells to the endothelium, while $\mathrm{Zn}$ chelation diminishes cell recruitment (Chavakis et al. 1999). Thus, $\mathrm{Zn}$ is essential even in the earliest stages of an immune response. In vivo, $\mathrm{Zn}$ deficiency not only influences the recruitment of neutrophils but also decreases the chemotaxis of neutrophils. Under these conditions there is also impaired natural 
killer cell activity, phagocytosis of macrophages and neutrophils, and generation of the oxidative burst (Allen et al. 1983; Keen \& Gershwin, 1990). At the molecular level, $\mathrm{Zn}$ is required for the interaction between the p58 killer cell inhibitory receptor on NK cells and major histocompatibility complex (MHC) class I molecules, mainly human leucocyte antigen $\mathrm{C}$, on target cells (Rajagopalan et al. 1995), resulting in the inhibition of the killing activity. Interestingly, only the inhibitory signal is $\mathrm{Zn}$-dependent, whereas the human leucocyte antigen $\mathrm{C}$ interaction and positive signals do not require $\mathrm{Zn}$ (Rajagopalan et al. 1995). Thus, $\mathrm{Zn}$ is needed to maintain the normal function of natural killer cells, and Zn deficiency may result in non-specific killing activity and functional loss. It is not only the proliferation of the immune system which depends on $\mathrm{Zn}$; the proliferation of the pathogens is also $\mathrm{Zn}$-dependent. Thus, decreasing $\mathrm{Zn}$ in the plasma is an acute-phase response to infection. Furthermore, the S-100 $\mathrm{Ca}^{2+}$-binding protein calprotectin which is released by degradation of neutrophils inhibits reproduction of bacteria and Candida albicans by $\mathrm{Zn}$ chelation (Sohnle et al. 1991; Murthy et al. 1993; Clohessy \& Golden, 1995).

Despite the fact that innate immunity is the first stage in the response of the immune system, initial observations relating to the influence of $\mathrm{Zn}$ were associated with the development of T-cells due to thymic atrophy (Fraker et al. 1995; Osati-Ashtiani et al. 1998). $\mathrm{Zn}$ is an essential cofactor for the thymic hormone thymulin (a nonapeptide) (Bach, 1981, 1983). Thymulin is secreted by thymic epithelial cells and induces markers of differentiation in immature T-cells (Saha et al. 1995). However, thymulin also modulates cytokine release by PBMC and induces proliferation of CD8 T-cells in combination with IL-2 (Coto et al. 1992; Safie-Garabedian et al. 1993). Zn supplementation can reverse the changes induced by Zn deficiency in the thymus and on peripheral cells (Mocchegiani et al. 1995a). The addition of $\mathrm{Zn}$ alone can induce the expression of the high-affinity receptor for IL-2 (Tanaka et al. 1989); a factor which can result in decreased proliferation of T-cells in $\mathrm{Zn}$ deficiency (Dowd et al. 1986; Crea et al. 1990).

$\mathrm{Zn}$ ions have been reported to induce blast transformation in human lymphocytes (Kirchner \& Rühl, 1970; Rühl et al. 1971; Berger \& Skinner, 1974; Sood et al. 1999). Zn addition induced the release of IL-1, IL-6, tumour necrosis factor $\alpha$, soluble IL-2 receptor and interferon (IFN)- $\gamma$ in human PBMC (Salas \& Kirchner, 1987; Scuderi, 1990; Driessen et al. 1994). IL-1, IL-6, and tumour necrosis factor $\alpha$ are induced in monocytes in the absence of lymphocytes, whereas the induction of IFN- $\gamma$ is dependent on the presence of monocytes (Rühl \& Kirchner, 1978; Salas \& Kirchner, 1987; Driessen et al. 1994; Wellinghausen et al. 1997b; Fig. 1). Tumour necrosis factor $\alpha$ release after $\mathrm{Zn}$ stimulation of PBMC is a result of de novo mRNA transcription (Wellinghausen et al. 1996a). However, how Zn activates an intracellular signal and which signal transduction pathways are involved are still unknown. Further investigations showed that only isolated monocytes respond to $\mathrm{Zn}$ stimulation, whereas isolated T-cells (Hadden, 1995; Wellinghausen et al. 1997b), B-cells (Crea et al. 1990), natural killer cells (Crea et al. 1990) or neutrophils (A Fischer, P Gabriel and L Rink, unpublished results; Fig. 1) do not produce cytokines after induction with $\mathrm{Zn}$. The stimulation of monocytes and T-cells by $\mathrm{Zn}$ is dependent on the level of free $\mathrm{Zn}$ ions relative to the protein composition of the culture medium. Insulin and transferrin specifically enhance $\mathrm{Zn}$-induced monocyte activation by a non-receptordependent mechanism (Phillips \& Azari, 1974; Crea et al. 1990; Driessen et al. 1995c; Wellinghausen et al. 1996b), but high levels of serum proteins in the culture medium prevent monocyte stimulation. $\mathrm{Zn}$ concentrations $>100 \mu \mathrm{M}$ in a serum-free culture medium stimulate monocytes, but actually inhibit T-cell functions, since T-cells have a lower intracellular $\mathrm{Zn}$ concentration and are more susceptible to increasing Zn levels than monocytes (Bulgarini et al. 1989; Goode et al. 1989; Wellinghausen et al. 1997b; Fig. 1). The increase in intracellular free $\mathrm{Zn}$ in monocytes and T-cells is the same (Wellinghausen et al. 1996b, 1997b). The molecular background for this effect is the inhibition of the IL-1 type I receptor-associated kinase by $\mathrm{Zn}$, since T-cell stimulation by $\mathrm{Zn}$ is an indirect effect of IL-1 secreted by monocytes (Driessen et al. 1994; Wellinghausen et al. 1997b). Furthermore, Zn can alter the structure of ceramides (U Seydel, unpublished results) which are involved in the signal transduction of tumour necrosis factor and IL-1 (Wright \& Kolesnick, 1995). This effect is comparable with the conformational alteration of lipopolysaccharide (LPS), described later (Table 5; Wellinghausen et al. 1996c). In contrast to the amplifying effect on LPS, the function of ceramides as second messengers may be reduced and could be responsible also for the inhibition of tumour necrosis factor-induced apoptosis (Flieger et al. 1990).

As in vitro, an excess of $\mathrm{Zn}$ in vivo inhibits T-cell function (Duchateau et al. 1981; Chandra, 1984). In vitro levels $>50 \mu \mathrm{M}$ inhibit alloreactivity in the mixed lymphocyte reaction (aCampo et al. 2000). On the other hand, low serum $\mathrm{Zn}$ levels also alter normal T-cell functions. Some autoimmune diseases with a T-cell pathology, e.g. rheumatoid arthritis, are associated with moderate Zn deficiency (Simkin, 1976), and in some cases $\mathrm{Zn}$ supplementation was advantageous. Decreased plasma $\mathrm{Zn}$ levels in preganancy are associated with an increased

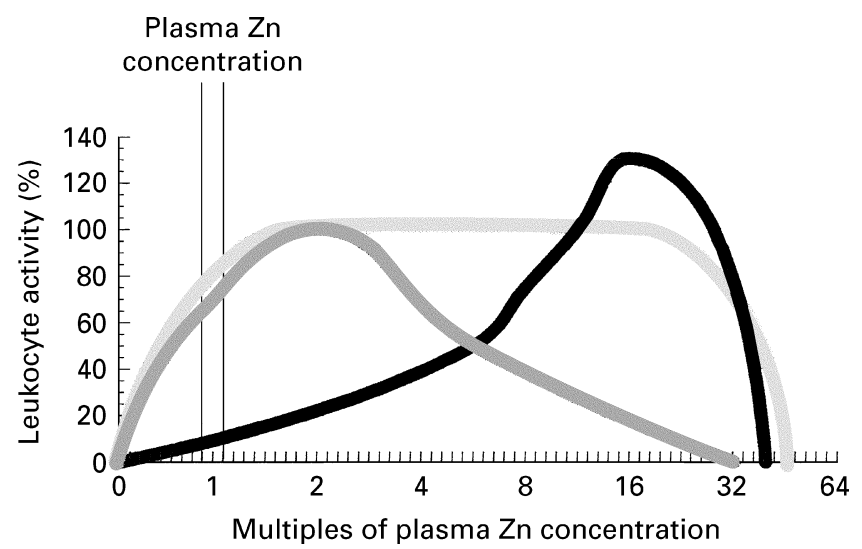

Fig. 1. Leucocyte activity and its dependence on plasma zinc concentrations. (口), lymphocytes; $(\boldsymbol{\square})$, monocytes; $(\square)$, granulocytes. Note that zinc activates monocytes to a greater extent than either granulocytes or lymphocytes. 
risk of preterm delivery and abortion (Favier, 1992; Jameson, 1993; Bedwal \& Bahuguna, 1994). This factor might be an effect of normally-suppressed alloreactive T-cells or non-specific natural killer cell activity. The physiological Zn concentrations, based on in vitro experiments, seem to be just below the optimal concentration for T-cell function (Fig. 1).

In contrast to the mechanisms involved in the inhibition of leucocytes, the direct activation of monocytes by $\mathrm{Zn}$ is still not understood. Tyrosine kinases as well as cAMPand cGMP-dependent protein kinases are clearly involved (Wellinghausen et al. 1996b). Intracellular cAMP and calmodulin are therefore influenced in a different manner (Brewer et al. 1979; Heng et al. 1993). Inhibition of intra-erythrocytic calmodulin-mediated effects is possibly responsible for the benefits of $\mathrm{Zn}$ supplementation in sickle cell disease (Brewer \& Bereza, 1982). In phospholipase C, $\mathrm{Zn}$ is integrated, in the active centre, but no stimulatory effects of $\mathrm{Zn}$ have been reported (Coleman, 1992a). $\mathrm{Zn}$ is necessary for the translocation of the PKC to the cell membrane, but an involvement of PKC in $\mathrm{Zn}$-induced signal transduction in PBMC has not been confirmed (Csermely et al. 1988; Wellinghausen et al. 1996b).

Zn might simply bind to specific membrane receptors, triggering a signal transduction cascade. On the other hand, however, Zn could also exert its effects directly inside the cell. Perhaps more important than a specific interaction between $\mathrm{Zn}$ and certain molecules is a general influence of $\mathrm{Zn}$ on the fluidity of lipids, and thus also of biological membranes (Chvapil, 1976; Kruse-Jarres, 1989; Bettger \& O’Dell, 1993). Membrane stabilization could have considerable consequences for the cell; for example, an activation or inhibition of ion channels and altered assembling of cell surface receptors, initiating or inhibiting signal transduction into the cell (Heldin, 1995).

In addition to its effects on upstream signalling molecules, $\mathrm{Zn}$ influences gene expression by structural stabilization and functional regulation of various immunologically-relevant transcription factors (Chesters, 1992; Coleman, 1992a; O’Halloran, 1993; Vallee \& Falchuk, 1993) as summarized earlier. However, the relationship between activation of specific transcription factors and $\mathrm{Zn}$-induced effects in PBMC still remains to be clarified.

\section{Interaction of zinc with immunostimulants}

The capacity of the immune system is measured using different outcome systems (e.g. proliferation, cytokine production) after stimulation of leucocytes in vivo or in vitro. Frequently used stimulants include lectins (e.g. phytohaemagglutinin; PHA), phorbol esters (e.g. phorbol 12-myristate 13-acetate), LPS, super-antigens (e.g. staphylococcal enterotoxins) or specific antigens inducing a recall response in most individuals (e.g. tetanus toxin or diphtheria toxin). Thus, to measure $\mathrm{Zn}$-specific alterations of immune function it must be established that the immunostimulant itself is not affected by $\mathrm{Zn}$. Indeed, the activity of many stimulants is influenced by $\mathrm{Zn}$. Interestingly, one of the early reports regarding the immunobiology of $\mathrm{Zn}$ described the co-mitogenic effect of PHA (Duchateau et al. 1981; Fraker et al. 1986; Warner \& Lawrence, 1986).
However, PHA is frequently used in vitro, but does not appear in human blood in vivo. Thus, it is of greater relevance that $\mathrm{Zn}$ influences the immunostimulative effects of LPS from Gram-negative bacteria and some bacterial superantigens (mainly produced by Gram-positive bacteria), as well as tetanus toxin and diphtheria toxin. Substimulatory concentrations of $\mathrm{Zn}$ enhanced the biological activity of LPS with respect to cytokine induction in leucocytes (Driessen et al. 1995a,b). This synergism depends on a Zninduced structural alteration of LPS in its biologically-moreactive less-fluid form (Wellinghausen et al. 1996c). LPS is an important pathogenic factor in sepsis, and $\mathrm{Zn}$ supplementation in patients with systemic Gram-negative infections or in intensive-care-unit patients may have devastating consequences if the activity of LPS is also enhanced in vivo. Recently, it was shown that parenteral $\mathrm{Zn}$ supplementation $(30 \mathrm{mg} / \mathrm{d})$ in septic patients exaggerated the acute-phase response, as indicated by a higher febrile response (Braunschweig et al. 1997). However, Klosterhalfen et al. (1996) reported that in a porcine sepsis model the induction of stress proteins by prophylactic administration of $\mathrm{Zn}$ can reduce the inflammatory response after LPS treatment. We recently found a time-dependent response in a mouse model (P Gabriel, J Schürman, G Tiegs and L Rink, unpublished results). If $\mathrm{Zn}$ is injected some minutes before LPS is administered it has a protective effect, whereas application simultaneously with or after LPS treatment resulted in a synergistic effect, as described earlier (Wellinghausen et al. 1996c). This finding may be explained by the influence of $\mathrm{Zn}$ on the IL-1 type 1 receptorassociated kinase as described earlier (p. 544), since the LPS signal transduction pathway via the toll-like receptors (members of the IL-1 receptor family) are also dependent on this kinase. Thus, $\mathrm{Zn}$ might be useful in the prophylactic treatment of patients at high-risk for sepsis, but unsuitable for already-septic patients.

The activity of some bacterial super-antigens is also influenced by $\mathrm{Zn}$ (Driessen et al. 1995a,b). There are different groups of super-antigens using binding sites on the MHC-II $\alpha$-chain, $\beta$-chain, or both sites. All super-antigens binding to the MHC-II $\beta$-chain (e.g. the Staphylococcus aureus enterotoxins A, D and E and the Mycoplasma arthritidis super-antigen) do so by forming a $\mathrm{Zn}$ cluster involving histidine- 81 of the MHC-II $\beta$-chain and three amino acids from the super-antigen (Fraser et al. 1992; Kim et al. 1994; Sundström et al. 1996; Bernatchez et al. 1997). Thus, binding to the MHC-II $\beta$-chain is $\mathrm{Zn}$-dependent. The interaction between these super-antigens and the MHC-II $\beta$ chain can be diminished by the chelation of $\mathrm{Zn}$ (Bernatchez et al. 1997). On the other hand, cytokine induction by those super-antigens can also be inhibited by the addition of high Zn concentrations (Driessen et al. 1995b), whereas superantigens binding to the $\mathrm{Zn}$-independent MHC-II $\alpha$-binding site (e.g. toxic shock syndrome toxin-1) are not influenced by $\mathrm{Zn}$ in any way. Without $\mathrm{Zn}$ the super-antigens cannot build up a $\mathrm{Zn}$ cluster with histidine-81 of the MHC-II $\beta$-chain, and it is likely that high $\mathrm{Zn}$ concentrations saturate both sites, thus preventing complex formation. However, $\mathrm{Zn}$ also mediates a super-antigen homodimerization, as recently described for S. aureus enterotoxins (Sundström et al. 1996). This homodimerization facilitates a T-cell- 
independent interaction between the super-antigen and MHC-II molecules, resulting in direct activation of monocytes. The inhibitory effect of $\mathrm{Zn}$ on super-antigens could be an interesting therapeutic perspective for the treatment of food poisoning, Gram-positive sepsis or staphylococcal infections in which super-antigens play a causative role. Furthermore, the production of some super-antigens (e.g. toxic shock syndrome toxin-1) seems to be regulated by $\mathrm{Zn}$ repressor elements, since $\mathrm{Zn}$ chelation increases the super-antigen production (Tierno \& Hanna, 1985; Balaban \& Novick, 1995; Balaban et al. 1998). Interestingly, diphtheria-toxin production is also regulated by a $\mathrm{Zn}$ repressor (Groman \& Judge, 1979; Pohl et al. 1997).

Phorbol 12-myristate 13-acetate, tetanus toxin and diphtheria toxin may also be influenced by $\mathrm{Zn}$, but there are no conclusive data available. Phorbol 12-myristate 13acetate directly activates PKC, and PKC is influenced by $\mathrm{Zn}$ as described earlier (p. 545). Tetanus toxin has a Zn-binding sequence in a region frequently used as a B- and T-cell epitope (Villiers et al. 1993). Zn saturation of this binding site leads to decreased recognition by antibodies and T-cells. Thus, $\mathrm{Zn}$ saturation of tetanus toxin may influence the outcome after tetanus toxin stimulation.

However, it is not only immunostimulants that are affected by $\mathrm{Zn}$, since cytokine functions and detection are modulated by Zn-activated $\alpha_{2}$-macroglobulin, which may also alter the outcome (James, 1990). In conclusion, it is difficult to find an immunostimulant and test system completely independent of $\mathrm{Zn}$ in its function in vivo or in vitro.

\section{Zinc therapy and in vitro zinc supplementation}

$\mathrm{Zn}$ has diverse effects on immune functions. During $\mathrm{Zn}$ deficiency different immune functions are decreased (Table 6; Wellinghausen et al. 1997a). All these impaired functions are completely restored by $\mathrm{Zn}$ supplementation. Since the defect in some immunological functions is related to a lack of the relevant leucocyte subset, only some of the functions were restored in vitro (Cakman et al. 1996, 1997).

$\mathrm{Zn}$ administration is the standard therapy for acrodermatitis enteropathica, as well as in non-specific malabsorption syndromes (Neldner \& Hambidge, 1975; CunninghamRundles et al. 1980). The Zn supplement reversed immunological defects as well as other Zn-deficiency-associated syndromes. Furthermore, $\mathrm{Zn}$ supplementation is frequently used to compete with $\mathrm{Cu}$ for absorption in Wilson's diseases and to increase metallothionein.

Table 6. Immune functions which are decreased in zinc deficiency Periperhal T-cell count

T-cell proliferation in response to $\mathrm{PHA}$

Thymocyte count in thymus

Delayed-type hypersensitivity reaction

T-helper cell function

Cytotoxic T-cell activity

NK cell activity

Macrophage functions (phagocytosis, intracellular killing activity)

Neutrophil functions (chemotaxtis, oxidative burst)

Serum thymulin level
Various diseases are accompanied by altered $\mathrm{Zn}$ plasma levels. For some diseases the results of preliminary trials of $\mathrm{Zn}$ therapy have been published. Tables 7 and 8 summarize the diseases, the effects of $\mathrm{Zn}$ and the possible molecular mechanism associated with the beneficial effects of $\mathrm{Zn}$ therapy.

An interesting application of $\mathrm{Zn}$ is its use as an adjuvant in vaccination. Two groups of patients with reduced plasma $\mathrm{Zn}$ levels (the elderly, and haemodialysis patients) are known to have an impaired immune system and a poor response to vaccination (Sandstead et al. 1982; Lighart et al. 1984; Fraker et al. 1986; Bonomini et al. 1993; Cakman et al. 1996). The results of a number of vaccination trials which were accompanied by $\mathrm{Zn}$ supplementation have been published during the last two decades (Rawer et al. 1987; Grekas et al. 1992; Brodersen et al. 1995; Provinciali et al. 1998; Turk et al. 1998). The findings were extremely contradictory. This situation may be due to the lack of a standard level for $\mathrm{Zn}$ supplementation. In some studies extremely high $(400 \mathrm{mg} / \mathrm{d})$ levels of $\mathrm{Zn}$ were given, which have been shown in other trials to impair immune functions (reduced delayed-type hypersensitivity reaction occurs at a dose of $100 \mathrm{mg} / \mathrm{d}$; Porter et al. 1977; Chandra, 1984; Patterson et al. 1985; Provinciali et al. 1998; Reinhold et al. 1999; Rink \& Kirchner, 1999). We recently found that the response to diphtheria vaccination in haemodialysis patients is correlated with the actual plasma Zn level (Kreft et al. 2000). Possible mechanisms for this relationship are an increase in IFN- $\alpha$ production, as shown in vitro, or impaired T-cell functions (Sandstead et al. 1982; Cakman et al. 1996). However, high-dose $\mathrm{Zn}$ supplementation (seven to eight times the physiological level) in vitro inhibited T-cell functions and reduced IFN- $\alpha$ production. Thus, in order to reverse $\mathrm{Zn}$ deficiency, the pharmacological $\mathrm{Zn}$ dose should be adjusted in line with the actual requirements, and plasma Zn level should not exceed $30 \mu \mathrm{M}$.

The inhibitory effects of $\mathrm{Zn}$ may provide a new therapeutic tool for use in immunosuppressive therapy where a selective suppression of lymphocyte functions is desirable. Possible diseases are T-cell-mediated autoimmune diseases such as rheumatoid arthritis or graft $v$. host reactions following organ transplantation. We observed that $\mathrm{Zn}$ specifically inhibits the mixed lymphocyte culture (as an in vitro transplantation model) at concentrations of three to four times the physiological level.

\section{Conclusion}

It has been known for decades that $\mathrm{Zn}$ is essential for an intact immune system. However, experimental data and nutritional explanations for the precise function and daily intake requirements are few or contradictory. The problem is the differentiation of the effects of $\mathrm{Zn}$ on general cell growth and function, the specific effects on cells of the immune system or alterations of the outcome system via an effect on the immunostimulants. Furthermore, normal immune function is delicately regulated by the $\mathrm{Zn}$ level, and $\mathrm{Zn}$ deficiency, as well as Zn levels $>50 \mu \mathrm{M}$, alter normal immune functions. Fig. 1 shows that the function of leucocytes is dependent on the $\mathrm{Zn}$ concentration. Thus, therapeutic $\mathrm{Zn}$ administration must be adjusted according

PHA, phytohaemagglutinin; NK, natural killer 
Table 7. Zinc therapy studies

\begin{tabular}{|c|c|c|c|c|}
\hline Disease or disorder & Symptoms & Effect of $\mathrm{Zn}$ supplementation $\mathrm{F}$ & Possible mechanism & Reference \\
\hline $\begin{array}{l}\text { Cutaneous } \\
\text { leishmaniasis }\end{array}$ & $\begin{array}{l}\text { Ulcerative lesions } \\
\text { susceptible to secondary } \\
\text { infections }\end{array}$ & $\begin{array}{l}\text { Decrease of disease } \\
\text { activity }\end{array}$ & $\begin{array}{l}\text { Leishmania is sensitive to } \\
\text { zinc sulfate }\end{array}$ & Najim et al. (1998) \\
\hline Growth retardation & $\begin{array}{l}\text { Deficiency in the secretory } \\
\text { activity of the testis, } \\
\text { hypogonadism (male) }\end{array}$ & $\begin{array}{l}\text { Recovery of testical } \\
\text { functions, normalization } \\
\text { of overall growth }\end{array}$ & $\begin{array}{l}\text { Reactivation of enzymes } \\
\text { and transcription } \\
\text { factors }\end{array}$ & Prasad $(1995,1996)$ \\
\hline Cystic fibrosis & Impaired $\mathrm{Zn}$ absorption & $\begin{array}{l}\text { Improved } \mathrm{Zn} \text { absorption by } \\
\text { enzyme replacement }\end{array}$ & $\begin{array}{l}\text { Re-activation of enzymes } \\
\text { and transcription factors }\end{array}$ & Easley et al. (1998) \\
\hline Parkinson's disease & Tremor & $\begin{array}{l}\text { Reduction of Parkinson } \\
\text { symptoms }\end{array}$ & $\begin{array}{l}\text { Inhibition of } \beta \text {-carboline- } \\
2-N \text {-methyltransferase }\end{array}$ & Gearhart et al. (1997) \\
\hline $\begin{array}{l}\text { Wilson's disease } \\
\text { (WD) }\end{array}$ & $\begin{array}{l}\text { Kayser-Fleischer-rings } \\
\text { (cornea), muscle rigidity } \\
\text { and dementia }\end{array}$ & $\begin{array}{l}\text { Reduces Cu absorption } \\
\text { and Kayser-Fleischer } \\
\text { rings in size. Increases } \\
\text { metallothionein in } \\
\text { presymptomatic WD } \\
\text { patient }\end{array}$ & $\begin{array}{l}\text { Inhibits Cu resorption } \\
\text { Induced metallothionein } \\
\text { synthesis which also } \\
\text { prevents } \mathrm{Cu} \text { accumulation }\end{array}$ & $\begin{array}{l}\text { Brewer \& Yuzbasiyan-Gurkan } \\
\text { (1992), Brewer et al. (1994), } \\
\text { Esmaeli et al. (1996), } \\
\text { Shimizu et al. (1999), } \\
\text { Sturniolo et al. (1999) }\end{array}$ \\
\hline Sickle cell disease & $\begin{array}{l}\text { Hyperzincuria causes an } \\
\text { impaired cell-mediated } \\
\text { immunity }\end{array}$ & $\begin{array}{l}\text { Increase in lymphocyte } \\
\text { function and IL-2 } \\
\text { production. Decreased } \\
\text { hospitalizations and } \\
\text { vaso-occlusive pain }\end{array}$ & $\begin{array}{l}\text { Reconstitution of thymocyte } \\
\text { functions }\end{array}$ & Prasad et al. (1999) \\
\hline Common cold & $\begin{array}{l}\text { Rhinitis, tearing, low-grade } \\
\text { fever and malaise }\end{array}$ & $\begin{array}{l}\text { Zinc gluconate reduces the } \\
\text { duration of symptoms }\end{array}$ & $\begin{array}{l}\text { Cell membrane } \\
\text { stabilization to reduce } \\
\text { viral penetration. Altered } \\
\text { viral capsid formation. } \\
\text { Increased IFN- } \alpha \\
\text { production }\end{array}$ & $\begin{array}{l}\text { Mossad et al. (1996), } \\
\text { Cakman et al. (1997) }\end{array}$ \\
\hline Hypozincaemia & $\begin{array}{l}\text { Increased incidence of } \\
\text { concomitant systematic } \\
\text { bacterial infections }\end{array}$ & $\begin{array}{l}\text { Zn supplementation } \\
\text { can reduce bacterial } \\
\text { infections }\end{array}$ & $\begin{array}{l}\text { Reconstitution of thymocyte } \\
\text { functions, increased NK } \\
\text { and phagocytotic activity }\end{array}$ & Worwag et al. (1999) \\
\hline $\begin{array}{l}\text { Acrodermatitis } \\
\text { enteropathica }\end{array}$ & $\begin{array}{l}\text { Vesicles and bullae of the } \\
\text { skin and mucous } \\
\text { membranes, alopecia, } \\
\text { diarrhoea and failure to } \\
\text { thrive. Autosomal recessive } \\
\text { disorder of } Z n \text { resorption }\end{array}$ & $\begin{array}{l}\text { Zn therapy reverses all } \\
\text { symptoms }\end{array}$ & $\begin{array}{l}\text { Reactivation of enzymes } \\
\text { and transcription factors, } \\
\text { reconstitution of } \\
\text { thymocyte functions, } \\
\text { increased NK and } \\
\text { phagocytotic activity }\end{array}$ & Prasad (1995) \\
\hline AIDS & $\begin{array}{l}\text { Increased apoptosis } \\
\text { of immune cells. } \\
\text { Hypozincaemia } \\
\text { associated with increased } \\
\text { opportunistic infections }\end{array}$ & $\begin{array}{l}\text { Decreased apoptosis and } \\
\mathrm{Zn} \text { is an adjunct to AZT } \\
\text { therapy in AIDS pathology }\end{array}$ & $\begin{array}{l}\mathrm{Zn} \text { inhibits T-cell apoptosis } \\
\text { and increases thymocyte } \\
\text { proliferation }\end{array}$ & $\begin{array}{l}\text { Mocchegiani et al. (1995b), } \\
\text { Neves et al. (1998), } \\
\text { Wellinghausen et al. (2000) }\end{array}$ \\
\hline $\begin{array}{l}\text { Rheumatoid arthritis } \\
\text { (RA) }\end{array}$ & $\begin{array}{l}\text { Lower level of } \mathrm{Zn} \text { may be } \\
\text { due to an accumulation } \\
\text { of } \mathrm{Zn} \text {-containing proteins } \\
\text { in the liver and in the } \\
\text { inflamed joints in RA }\end{array}$ & Decreased symptoms & $\begin{array}{l}\text { Impairment of PMN } \\
\text { phagocytosis, T-cell } \\
\text { suppression and blocking } \\
\text { IL-1 signal transduction }\end{array}$ & $\begin{array}{l}\text { Zoli et al. (1998), } \\
\text { Wellinghausen et al. } \\
(1997 b)\end{array}$ \\
\hline $\begin{array}{l}\text { Herpes simplex } \\
\text { virus }\end{array}$ & $\begin{array}{l}\text { Small, transient, irritating } \\
\text { and sometimes painful } \\
\text { fluid-filled blisters on } \\
\text { the skin and mucous } \\
\text { membranes }\end{array}$ & Shortening infection & $\begin{array}{l}\text { Inhibition of virion functions } \\
\text { by binding to sulfhydryl } \\
\text { groups of glycoprotein B } \\
\text { and increased IFN- } \alpha \\
\text { production }\end{array}$ & $\begin{array}{l}\text { Varadinova et al. (1993), } \\
\text { Cakman et al. (1996) }\end{array}$ \\
\hline Down syndrome & $\begin{array}{l}\text { Immature myeloid cells in } \\
\text { the peripheral blood }\end{array}$ & $\begin{array}{l}\text { Haematological symptoms } \\
\text { reversed }\end{array}$ & $\begin{array}{l}\text { Direct effects on leucocytes } \\
\text { and on thymus hormones }\end{array}$ & $\begin{array}{l}\text { Trubiani et al. (1996), } \\
\text { Antonucci et al. (1997) }\end{array}$ \\
\hline Crohn's disease & $\begin{array}{l}\text { Decreased } \mathrm{Zn} \text { levels lead } \\
\text { to acrodermatitis } \\
\text { enteropathica and } \\
\text { decreased visual acuity }\end{array}$ & $\begin{array}{l}\text { Alleviation of skin lesions } \\
\text { and improvement of visual } \\
\text { acuity. Low plasma concen- } \\
\text { trations of thymulin restored }\end{array}$ & $\begin{array}{l}\text { T-cell suppression and } \\
\text { thymus reconstitution }\end{array}$ & $\begin{array}{l}\text { Brignola et al. (1993), } \\
\text { Krasovec \& Frenk (1996), } \\
\text { Myung et al. (1998) }\end{array}$ \\
\hline
\end{tabular}

AIDS, acquired immune deficiency syndrome; AZT, zidovudine; IL, interleukin; IFN, interferon; NK, natural killer; PMN, polymorphonuclear leucocyte.

to the plasma $\mathrm{Zn}$ level. On the other hand, $\mathrm{Zn}$ can be used as an immunosuppressant with low toxicity. Last, but not least, both in vivo and in vitro the adequacy of the $\mathrm{Zn}$ concentration must be taken into account whenever abnormal cellular functions are observed. This approach is not restricted to the immune system, but the immune system is the first system to be affected by changing $\mathrm{Zn}$ levels, due to its high cell turnover. 
Table 8. Diseases associated with altered zinc levels

\begin{tabular}{|c|c|c|c|}
\hline Disease & Plasma Zn level & Type of disorder & Reference \\
\hline Alzheimer's disease & elevated & $\begin{array}{l}\text { Zn-mediated NF-kB activation resulting in the activation of the amyloid } \\
\text { precursor protein (APP) promoter region. APP forms amyloid- } \beta \text { and } Z n \\
\text { inhibits the modulation of APP into non-amyloidogenic peptides. Amyloid- } \beta \text { - } \\
\text { protein forms Ca-permeable and Zn-sensitive channels resulting in cellular } \\
\text { toxicity }\end{array}$ & $\begin{array}{l}\text { Kawahara et al. } \\
\quad(1997), \\
\text { Lin et al. (1999) }\end{array}$ \\
\hline Hyperzincaemia & elevated & $\begin{array}{l}\text { Plasma levels }>200 \mu \mathrm{M} \text { cause symptoms consistent with Zn deficiency, } \\
\text { probably an inborn defect of Zn metabolism }\end{array}$ & Sampson et al. (1997) \\
\hline Depression & decreased & $\begin{array}{l}\mathrm{Zn} \text { deficiency impairs neuro- and immunoactivity of the mammalian } \\
\text { organisms. Hypozincaemia in severe depression may be related to activation } \\
\text { of cell-mediated immunity in that illness. T-cell suppression and modulation of } \\
\text { neurotransmitter systems }\end{array}$ & $\begin{array}{l}\text { Nowak (1998), } \\
\text { Nowak \& Schlegel- } \\
\text { Zawadzka (1999) }\end{array}$ \\
\hline Preterm delivery & decreased & Decreased plasma $\mathrm{Zn}$ levels are associated with preterm delivery and abortion & Scholl et al. (1993) \\
\hline
\end{tabular}

\section{References}

aCampo C, Wellinghausen N, Faber C, Fischer A \& Rink L (2000) Zinc inhibits the mixed lymphocyte culture. Biological Trace Element Research (In the Press).

Aicher WK, Heer AH, Trabandt A, Bridges SL Jr, Schroeder HW Jr, Stransky G, Gay RE, Eibel H, Peter HH, Siebenlist U, Koopman WJ \& Gay S (1994) Overexpression of zinc-finger transcription factor $\mathrm{z}-225 / \mathrm{Egr}-1$ in synoviocytes from rheumatoid arthritis patients. Journal of Immunology 152, 5940-5948.

Aicher WK, Sakamoto KM, Hack A \& Eibel H (1999) Analysis of functional elements in the human Egr-1 gene promoter. Rheumatology International 8, 207-214.

Allen JI, Perri RT, McClain CJ \& Kay NE (1983) Alterations in human natural killer cell activity and monocyte cytotoxicity induced by zinc deficiency. Journal of Laboratory and Clinical Medicine 102, 577-589.

Andres ME, Burger C, Peral-Rubio MJ, Battaglioli E, Anderson ME, Grimes J, Dallman J, Ballas N \& Mandel G (1999) CoREST: a functional corepressor required for regulation of neural-specific gene expression. Proceedings of the National Academy of Sciences USA 96, 9873-9878.

Antonucci A, Di-Baldassarre A, Di-Giacomo F, Stuppia L \& Palka G (1997) Detection of apoptosis in peripheral blood cells of 31 subjects affected by Down syndrome before and after zinc therapy. Ultrastructural Pathology 21, 449-452.

Armstrong RC, Kim JG \& Hudson LD (1995) Expression of myelin transcription factor I (MyTI), a 'zinc-finger' DNA-binding protein, in developing oligodendrocytes. Glia 14, 303-321.

Bach JF (1981) The multi-faceted zinc dependency of the immune system. Immunology Today 4, 225-227.

Bach JF (1983) Thymulin (FTS-Zn). Clinics in Immunology and Allergy 3, 133-150.

Balaban N, Goldkorn T, Nhan RT, Dang LB, Scott S, Ridgley RM, Rasooly A, Wright SC, Larrick JW, Rasooly R \& Carlson JR (1998) Autoinducer of virulence as a target for vaccine and therapy against Staphylococcus aureus. Science 280, 438-440.

Balaban N \& Novick RP (1995) Autocrine regulation of toxin synthesis by Staphylococcus aureus. Proceedings of the National Academy of Sciences USA 92, 1619-1623.

Bedwal RS \& Bahuguna A (1994) Zinc, copper and selenium in reproduction. Experientia 50, 626-640.

Bentley PJ (1992) Influx of zinc by channel catfish (Ictalurus punctatus): uptake from external environmental solutions. Comparative Biochemistry and Physiology 101C, 215-217.

Berger NA \& Skinner M (1974) Characterization of lymphocyte transformation induced by zinc ions. Journal of Cellular Biology 61, 45-55.
Bernatchez C, Al-Daccak R, Mayer PE, Mehindate K, Rink L, Mecheri S \& Mourad W (1997) Functional analysis of Mycoplasma arthritidis-derived mitogen interaction with class II molecules. Infection and Immunity 65, 2000-2005.

Bettger WJ \& O'Dell BL (1993) Physiological roles of zinc in the plasma membrane of mammalian cells. Journal of Nutritional Biochemistry 4, 194-207.

Bonomini M, Di Paolo B, De Risio F, Niri L, Klinkmann H, Ivanowich P \& Albertazzi A (1993) Effects of zinc supplementation in chronic haemodialysis patients. Nephrology Dialysis and Transplantation 8, 1166-1168.

Braunschweig CL, Sowers M, Kovacevich DS, Hill GM \& August DA (1997) Parenteral zinc supplementation in adult humans during the acute phase response increases the febrile response. Journal of Nutrition 127, 70-74.

Brewer GJ, Aster JC, Knutsen CA \& Kruckeberg WC (1979) Zinc inhibition of calmodulin: a proposed molecular mechanism of zinc action on cellular functions. American Journal of Hematology 7, 53-60.

Brewer GJ \& Bereza UL (1982) Therapy of sickle cell anemia with membrane expander/calmodulin inhibitor classes of drugs. In Clinical, Biochemical, and Nutritional Aspects of Trace Elements, pp. 211-220 [AS Prasad, editor]. New York: Liss.

Brewer GJ, Dick RD, Yuzbasiyan-Gurkan V, Johnson V \& Wang Y (1994) Treatment of Wilson's disease with zinc. XIII: Therapy with zinc in presymptomatic patients from the time of diagnosis. Journal of Laboratory and Clinical Medicine 123, 849-858.

Brewer GJ \& Yuzbasiyan-Gurkan V (1992) Wilson disease. Medicine 71, 139-164.

Brignola C, Belloli C, DeSimone G, Evangelisti A, Parente R, Mancini R, Innan P, Mocchegiani E, Fabris N \& Morini MC (1993) Zinc supplementation restores plasma concentrations of zinc and thymulin in patients with Crohn's disease. Alimentary and Pharmacology and Therapeutics 7, 275-280.

Brodersen HP, Holtkamp W, Larbig D, Beckers B, Thiery J, Lautenschlager J, Probst HJ, Ropertz S \& Yavari A (1995) Zinc supplementation and hepatitis $\mathrm{B}$ vaccination in chronic haemodialysis patients a multicentre study. Nephrology Dialysis Transplantation 10, 1780.

Bulgarini D, Habetswallner D, Boccoli G, Montesoro E, Camagna A, Mastroberardino G, Rosania C, Testa U \& Peschle C (1989) Zinc modulates the mitogenic activation of human peripheral blood lymphocytes. Annali dell Istituto Superiore di Sanita 25, 463-470.

Cakman I, Kirchner H \& Rink L (1997) Zinc supplementation reconstitutes the production of interferon- $\alpha$ by leukocytes from elderly persons. Journal of Interferon and Cytokine Research 17, 469-472. 
Cakman I, Rohwer J, Schütz RM, Kirchner H \& Rink L (1996) Dysregulation between $\mathrm{TH} 1$ and $\mathrm{TH} 2 \mathrm{~T}$ cell subpopulations in the elderly. Mechanisms of Ageing and Development 87, 197-209.

Chalaux E, Lopez-Rovira T, Rosa JL, Pons G, Boxer LM, Batrons $R$ \& Ventura F (1999) A zinc-finger transcription factor induced by TGF-beta promotes apoptotic cell death in epithelial Mv1Lu cells. FEBS Letters 457, 478-482.

Chandra RK (1984) Excessive intake of zinc impairs immune responses. Journal of the American Medical Association 252, 1443-1446.

Chang CC, Ye BH, Chaganti RS \& Dalla-Favera R (1996) BCL-6, a POZ/zinc-finger protein, is a sequence-specific transcriptional repressor. Proceedings of the National Academy of Sciences USA 93, 6947-6952.

Chavakis T, May AE, Preissner KT \& Kanse SM (1999) Molecular mechanisms of zinc-dependent leukocyte adhesion involving the urokinase receptor and $\beta_{2}$-integrins. Blood 93, 2976-2983.

Chesters JK (1992) Trace elements-gene interactions. Nutrition Reviews 50, 217-223.

Chvapil M (1976) Effect of zinc on cells and biomembranes. Medical Clinics of North America 60, 799-812.

Clohessy PA \& Golden BE (1995) Calprotectin-mediated zinc chelation as a biostatic mechanism in host defense. Scandinavian Journal of Immunology 42, 551-556.

Coleman JE (1992a) Zinc proteins: Enzymes, storage proteins, transcription factors and replication proteins. Annual Review of Biochemistry 16, 897-946.

Coleman JE (1992b) Structure and mechanism of alkaline phosphatase. Annual Review of Biophysics and Biomolecular Structure 21, 441-483.

Coto JA, Hadden EM, Sauro M, Zorn N \& Hadden JW (1992) Interleukin 1 regulates secretion of zinc-thymulin by human thymic epithelial cells and its action on T-lymphocyte proliferation and nuclear protein kinase C. Proceedings of the National Academy of Sciences USA 89, 7752-7756.

Crea A, Guérin V, Ortega F \& Hartemann P (1990) Zinc et système immunitaire (Zinc and immune system). Annales de Medecine Interne 141, 447-451.

Csermely P, Szamel M, Resch K \& Somogyi J (1988) Zinc can increase the activity of protein kinase $\mathrm{C}$ and contributes to its binding to plasma membrane in $\mathrm{T}$ lymphocytes. Journal of Biological Chemistry 263, 6487-6490.

Cunningham-Rundles S, Bockman RS, Lin A, Giardina PV, Hilgartner MW, Caldwell-Brown D \& Carter DM (1980) Physiological and pharmacological effects of zinc on immune response. Annals of the New York Academy of Sciences 587, 113-122.

De-Rinaldis E, Pisaneschi G, Camacho-Vanegas O \& Beccari E (1998) The binding sites for Xenopus laevis FIII/YY1 in the first exon of L1 and L14 ribosomal protein genes are dispensable for promoter expression. European Journal of Biochemistry $\mathbf{2 5 5}$, 563-569.

Deuel TF, Guan LS \& Wang ZY (1999) Wilms tumor gene product WT1 arrests macrophage differentiation of HL-60 cells through its zinc-finger domain. Biochemical and Biophysical Research Communications 254, 192-196.

Dowd PS, Kelleher J \& Guillou PJ (1986) T-lymphocyte subsets and interleukin-2 production in zinc-deficient rats. British Journal of Nutrition 55, 59-69.

Driessen C, Hirv K, Kirchner H \& Rink L (1995a) Divergent effects of zinc on different bacterial pathogenic agents. Journal of Infectious Diseases 171, 486-489.

Driessen C, Hirv K, Kirchner H \& Rink L (1995b) Zinc regulates cytokine induction by superantigens and lipopolysaccharide. Immunology 84, 272-277.
Driessen C, Hirv K, Rink L \& Kirchner H (1994) Induction of cytokines by zinc ions in human peripheral blood mononuclear cells and separated monocytes. Lymphokine and Cytokine Research 13, 15-20.

Driessen C, Hirv K, Wellinghausen N, Kirchner H \& Rink L (1995c) Influence of serum on zinc, toxic shock syndrome toxin-1, and lipopolysaccharide-induced production of IFN- $\gamma$ and IL-1 $\beta$ by human mononuclear cells. Journal of Leukocyte Biology 57, 904-908.

Duchateau J, Delespesse G \& Vereecke P (1981) Influence of oral zinc supplementation on the lymphocyte response to mitogens of normal subjects. American Journal of Clinical Nutrition 34, 88-93.

Easley D, Krebs N, Jefferson M, Miller L, Erskine J, Accurso F \& Hambidge KM (1998) Effect of pancreatic enzymes on zinc absorption in cystic fibrosis. Journal of Pediatric Gastroenterology and Nutrition 26, 136-139.

Esmaeli B, Burnstine MA, Martonyi CL, Sugar A, Johnson V \& Brewer GJ (1996) Regression of Kayser-Fleischer rings during oral zinc therapy: correlation with systemic manifestation of WD. Cornea 15, 582-588.

Favier A \& Favier M (1990) Consequences des deficits en zinc durant la grossesse pour la mère et le nouveau-né (Consequences of zinc deficits during pregnancy for the mother and newborn). Revue Française de Gynecologie et d'Obstetrique 85, 13-27.

Favier AE (1992) The role of zinc in reproduction. Hormonal mechanisms. Biological Trace Element Research 32, 363-382.

Feduchi E, Gallego MI \& Lazo PA (1994) The human zinc-finger protein-7 gene is located $90 \mathrm{~kb} 3^{\prime}$ of MYC and is not expressed in Burkitt lymphoma cell lines. International Journal of Cancer 58, 855-859.

Flieger D, Riethmüller G \& Ziegler-Heitbrock HWL (1990) Zn ${ }^{2+}$ inhibits both tumor necrosis factor-mediated DNA fragmentation and cytolysis. International Journal of Cancer 44, 315-319.

Fraker PJ, Gershwin ME, Good RA \& Prasad A (1986) Interrelationships between zinc and immune functions. Federation Proceedings 45, 1474-1479.

Fraker PJ, Osati-Ashtiani F, Wagner MA \& King LE (1995) Possible roles for glucocorticoids and apoptosis in the suppression of lymphopoiesis during zinc deficiency: a review. Journal of the American College of Nutrition 14, 11-17.

Fraser JD, Urban RG, Strominger JL \& Robinson H (1992) Zinc regulates the function of two superantigens. Proceedings of the National Academy of Sciences USA 89, 5507-5511.

Fukamachi Y, Karasaki Y, Sugiura T, Itoh H, Yamamura K \& Higashi K (1998) Zinc suppresses apoptosis of U937 cells induced by hydrogen peroxide through an increase of the Bcl-2/ Bax ratio. Biochemical and Biophysical Research Communications 246, 364-369.

Gearhart DA, Neafsey EJ \& Collins MA (1997) Characterization of brain beta-carboline-2-N-methyltransferase, an enzyme that may play a role in idiopathic Parkinson's disease. Neurochemical Research 22, 113-121.

German Society of Nutrition (1995) Ausschuß Nahrungsbedarf der DGE Zufuhrempfehlungen und Nährstoffbedarf. Teil II: Vergleich der Vorschläge von SCF/EC mit den Empfehlungen der DGE (Dietary requirements committee of DGE recommended intakes and nutrient requirements. Part 2. Comparison of proposals of SCF/EC with the recommendations of DGE). Ernährungsumschau 42, 4-10.

Goode HF, Kelleher J \& Walker BE (1989) Zinc concentrations in pure populations of peripheral blood neutrophils, lymphocytes and monocytes. Annals of Clinical Biochemistry 26, 89-95.

Greskas D, Alivanis P, Kotzadamis N, Kiriazopoulos M \& Tourkantonis A (1992) Influenza vaccination in chronic hemodialysis patients. The effect of zinc supplementation. Renal Failure 14, 575-578. 
Groman N \& Judge K (1979) Effect of metal ions on diphteria toxin production. Infection and Immunity 26, 1065-1070.

Hadden JW (1995) The treatment of zinc is an immunotherapy. International Journal of Immunopharmacology 17, 697-701.

Heldin CH (1995) Dimerization of cell surface receptors in signal transduction. Cell 80, 213-223.

Heng MK, Song MK \& Heng MCY (1993) Reciprocity between tissue calmodulin and cAMP levels: modulation by excess zinc. British Journal of Dermatology 129, 280-285.

Hogstrand C, Verbost PM, Bonga SE \& Wood CM (1996) Mechanisms of zinc uptake in gills of freshwater rainbow trout: interplay with calcium transport. American Journal of Physiology 270, R1141-R1147.

Humeny A, Bokenkamp D \& Thole HH (1999) The HDQVH-motif in domain $\mathrm{E}$ of the estradiol receptor alpha is responsible for zinc-binding and zinc-induced hormone release. Molecular and Cellular Endocrinology 153, 71-78.

Hynes M, Stone DM, Dowd M, Pitts-Meek S, Goddard A, Gurney A \& Rosenthal A (1997) Control of cell pattern in the neural tube by the zinc finger transcription factor and oncogene Gli-1. Neuron 19, 15-26.

Ishido M, Suzuki T, Adachi T \& Kunimoto M (1999) Zinc stimulates DNA synthesis during its antiapoptotic action independently with increments of an antiapoptotic protein, Bcl-2, in porcine kidney LLC-PK cells. Journal of Pharmacology and Experimental Therapeutics 290, 923-928.

James K (1990) Interaction between cytokines and $\alpha_{2}$-macroglobulin. Immunology Today 11, 163-166.

Jameson S (1993) Zinc status in pregnancy: the effect of zinc therapy on perinatal mortality, prematurity, and placental ablation. Annals of the New York Academy of Sciences 678, 178-192.

Jiang S, Chow SC, McCabe MJ Jr \& Orrenius S (1995) Lack of $\mathrm{Ca} 2+$ involvement in thymocyte apoptosis induced by chelation of intracellular Zn2+. Laboratory Investigation 73, 111-117.

Kawahara M, Arispe N, Kuroda Y, Rojas E (1997) Alzheimer's disease amyloid beta-protein forms $\mathrm{Zn}(2+)$-sensitive, cationselective channels across excised membrane patches from hypothalamic neurons. Biophysical Journal 73, 67-75.

Keen CL \& Gershwin ME (1990) Zinc deficiency and immune function. Annual Review of Nutrition 10, 415-431.

Kim J, Urban RG, Strominger JL \& Wiley DC (1994) Toxic shock syndrome toxin-1 complexed with a class II major histocompatibility molecule HLA-DR1. Science 266, 1870-1878.

Kirchner H \& Rühl H (1970) Stimulation of human peripheral lymphocytes by $\mathrm{Zn}^{2+}$ in vitro. Experimental Cell Research 61, 229-230.

Klaiman AP, Victery W, Kluger MJ \& Vander AJ (1981) Urinary excretion of zinc and iron following acute injection of dead bacteria in dog. Proceedings of the Society for Experimental Biology and Medicine 167, 165-171.

Klosterhalfen B, Töns C, Hauptmann S, Tietze L, Offner FA, Küpper W \& Kirkpatrick CJ (1996) Influence of heat shock protein 70 and metallothionein induction by zinc-bis-(DLhydrogenaspartate) on the release of inflammatory mediators in a porcine model of recurrent endotoxemia. Biochemical Pharmacology 52, 1201-1210.

Krasovec M \& Frenk E (1996) Acrodermatitis enteropathica secondary to Crohn's disease. Dermatology 193, 361-363.

Kreft B, Fischer A, Krüger S, Sack K, Kirchner H \& Rink L (2000) The impaired immune response to diphtheria vaccination in elderly chronic hemodialysis patients is related to zinc deficiency. Biogerontology 1, 61-66.

Kruse-Jarres JD (1989) The significance of zinc for humoral and cellular immunity. Journal of Trace Elements and Electrolytes in Health and Diseases 3, 1-8.
Lighart GJ, Coberand JX, Fournier C, Galanaud P, Hijmans W, Kennes B, Müller-Hermelink HK \& Steinmann GG (1984) Admission criteria for immunogerontological studies in man: The Senieur Protocol. Mechanisms of Ageing and Development 28, 47-55.

Lin H, Zhu YJ \& Lal R (1999) Amyloid beta protein (1-40) forms calcium permeable, $\mathrm{Zn} 2+$-sensitive channel in reconstituted lipid vesicles. Biochemistry 38, 11189-11196.

Maret W (1998) The glutathione redox state and zinc mobilization from metallothionein and other proteins with zinc-sulfur coordination sites. In Glutathione in the Nervous System, pp. 257-273 [CA Shaw, editor]. Philadelphia, PA: Taylor \& Francis.

Maret W, Jacob C, Vallee BL \& Fischer EH (1999) Inhibitory sites in enzymes: Zinc removal and reactivation by thionein. Proceedings of the National Academy of Sciences USA 96, 1936-1940.

Mills CF (1989) Zinc in Human Biology. Human Nutrition Reviews. London: Springer Verlag.

Mocchegiani E, Santarelli L, Muzzioli M \& Fabris N (1995a) Reversibility of the thymic involution and of age-related peripheral immune dysfunction by zinc supplementation in old mice. International Journal of Immunopharmacology 17, 703-718.

Mocchegiani E, Veccia S, Ancarani F, Scalise G \& Fabris N (1995b) Benefit of oral zinc supplementation as an adjunct to zidovudine (AZT) therapy against opportunistic infections in AIDS. International Journal of Immunopharmacology 17, 719-727.

Mossad SB, Macknin ML, Medendorp SV \& Mason P (1996) Zinc gluconate lozenges for treating the common cold. Annals of Internal Medicine 125, 81-88.

Muraosa Y, Takahashi K, Yoshizawa M \& Shibahara S (1996) cDNA cloning of a novel protein containing two zinc-finger domains that may function as a transcription factor for the human heme-oxygenase-1 gene. European Journal of Biochemistry 23, 471-479.

Murthy ARK, Lehrer RI, Harwig SSL \& Miyasaki KT (1993) In vitro candidastatic properties of the human neutrophil calprotectin complex. Journal of Immunology 151, 6291-6301.

Myung SJ, Yang SK, Jung HY, Jung SA, Kang GH, Ha HK, Hong WS \& Min Y (1998) Zinc deficiency manifested by dermatitis and visual dysfunction in a patient with Crohn's disease. Journal of Gastroenterology 33, 876-879.

Najim RA, Sharquie KE \& Farjou IB (1998) Zinc sulphate in the treatment of cutaneous leishmaniasis: an in vitro and animal study. Memorias do Instituto Oswaldo Cruz, 93, 831-837.

Nakayama H, Scott IC \& Cross JC (1998) The transition to endoreduplication in trophoblast giant cells is regulated by the mSNA zinc finger transcription factor. Developmental Biology 199, 150-163.

Neldner KH \& Hambidge KM (1975) Zinc therapy in acrodermatitis enteropathica. New England Journal of Medicine 292, 879-882.

Neves I Jr, Bertho AL, Veloso VG, Nascimento DV, CamposMello DL \& Morgado MG (1998) Improvement of the lymphoproliferative immune response and apoptosis inhibition upon in vitro treatment with zinc of peripheral blood mononuclear cells (PBMC) from HIV+ individuals. Clinical and Experimental Immunology 111, 264-268.

Nowak G (1998) Alterations in zinc homeostasis in depression and antidepressant therapy. Polish Journal of Pharmacology $\mathbf{5 0}$, $1-4$.

Nowak G \& Schlegel-Zawadzka M (1999) Alterations in serum and brain trace element levels after antidepressant treatment: part I. Zinc. Biological Trace Element Research 67, 85-92.

O'Halloran TV (1993) Transition metals in control of gene expression. Science 261, 715-725. 
Osati-Ashtiani F, King LE \& Fraker PJ (1998) Variance in the resistance of murine early bone marrow B cells to a deficiency in zinc. Immunology 94, 94-100.

Palmiter RD \& Findley SD (1995) Cloning and functional characterization of a mammalian zinc transporter that confers resistance to zinc. EMBO Journal 14, 639-649.

Palmiter RD, Cole TB \& Findley SD (1996a) ZnT-2, a mammalian protein that confers resistance to zinc by facilitating vesicular sequestration. EMBO Journal 15, 1784-1791.

Palmiter RD, Cole TB, Quaife CJ \& Findley SD (1996b) ZnT-3, a putative transporter of zinc into synaptic vesicles. Proceedings of the National Academy of Sciences USA 93, 14934-14939.

Patterson WP, Winkelmann M \& Perry MC (1985) Zinc-induced copper deficiency: megamineral sideroblastic anemia. Annals of Internal Medicine 103, 385-386.

Pavletich NP \& Pabo CO (1993) Crystal structure of a five-finger GLI-DNA complex: new perspectives on zinc fingers. Science 261, 1701-1707.

Philipsen S \& Suske G (1999) A tale of three fingers: the family of mammalian Sp/XKLF transcription factors. Nucleic Acids Research 27, 2991-3000.

Phillips JL \& Azari P (1974) Zinc transferrin: Enhancement of nucleic acid synthesis in phytohemagglutinin-stimulated human lymphocytes. Cellular Immunology 10, 31-37.

Pohl E, Qui X, Must LM, Holmes RK \& Hol WG (1997) Comparison of high-resolution structures of the diphteria toxin repressor in complex with cobalt and zinc at the cation-anion binding site. Protein Science 6, 1114-1118.

Porter KG, McMaster D, Elmes ME \& Love AH (1977) Anaemia and low serum-copper during zinc therapy. Lancet ii, 774.

Prasad AS (1995) Zinc: an overview. Nutrition 11, 93-99.

Prasad AS (1996) Zinc deficiency in women, infants and children. Journal of the American College of Nutrition 15, 113-120.

Prasad AS, Beck FW, Kaplan J, Chandrasekar PH, Ortega J, Fitzgerald JT \& Swerdlow P (1999) Effect of zinc supplementation on incidence of infections and hospital admission in sickle cell disease (SCD). American Journal of Hematology $\mathbf{6 1}$, 194-202.

Prasad AS, Miaie A Jr, Farid Z, Schulert A \& Sandstead HH (1963) Zinc metabolism in patients with the syndrome of iron deficiency, hypogonadism and dwarfism. Journal of Laboratory and Clinical Medicine 83, 537-549.

Provinciali M, Montenovo A, Di-Stefano G, Colombo M, Daghetta L, Cairati M, Veroni C, Cassino R, Della-Torre F \& Fabris N (1998) Effect of zinc or zinc plus arginine supplementation on antibody titre and lymphocyte subsets after influenza vaccination in elderly subjects: a randomized controlled trial. Age and Ageing 27, 715-722.

Rajagopalan S, Winter CC, Wagtmann N \& Long EO (1995) The Ig-related killer cell inhibitory receptor binds zinc and requires zinc for recognition of HLA-C on target cells. Journal of Immunology 155, 4143-4146.

Raulin J (1869) Etudes chimique sur la vegetation (Chemical studies on plants). Annales des Sciences Naturelles Botanique et Biologie Vegetale 11, 293-299.

Rawer P, Willems WR, Breidenbach T, Guttmann W, Pabst W \& Schutterle G (1987) Seroconversion rate hepatitis B vaccination, hemodialysis, and zinc supplementation. Kidney International 22S, 149-152.

Reinhold D, Ansorge S \& Grüngreiff K (1999) Immunobiology of zinc and zinc therapy. Immunology Today 20, 102.

Rink L \& Kirchner H (1999) Reply to Reinhold et al. Immunology Today 20, 102-103.

Rühl H \& Kirchner H (1978) Monocyte-dependent stimulation of human $\mathrm{T}$ cells by zinc. Clinical and Experimental Immunology 32, 484-488.
Rühl H, Kirchner H \& Borchert G (1971) Kinetics of the $\mathrm{Zn}^{2+}$ stimulation of human peripheral lymphocytes in vitro. Proceedings of the Society for Experimental Biology and Medicine 137, 1089-1092.

Safie-Garabedian B, Ahmed K, Khamashta MA, Taub NA \& Hughes GRV (1993) Thymulin modulates cytokine release by peripheral blood mononuclear cells: a comparison between healthy volunteers and patients with systemic lupus erythematodes. International Archives of Allergy and Immunology 101, $126-131$.

Saha AR, Hadden EM \& Hadden JW (1995) Zinc induces thymulin secretion from human thymic epithelial cells in vitro and augments splenocyte and thymocyte responses in vivo. International Journal of Immunopharmacology 17, 729-733.

Sakai Y, Nakagawa R, Sato R \& Maeda M (1998) Selection of DNA binding sites for human transcriptional regulator GATA-6. Biochemical and Biophysical Research Communications 250, 682-688.

Salas M \& Kirchner H (1987) Induction of interferon- $\gamma$ in human leukocyte cultures stimulated by $\mathrm{Zn}^{2+}$. Clinical Immunology and Immunopathology 45, 139-142.

Sampson B, Kovar IZ, Rauscher A, Fairweather-Tait S, Beattie J, McArdle HJ, Ahmed R \& Green C (1997) A case of hyperzincemia with functional zinc depletion: a new disorder? Pediatric Research 42, 219-225.

Sandstead HH, Henriksen LK, Greger JL, Prasad AS \& Good RA (1982) Zinc nutriture in the elderly in relation to taste acuity, immune response, and wound healing. American Journal of Clinical Nutrition 36, 1046-1059.

Schoenmakers E, Alen P, Verrijdt G, Peeters B, Verhoeven G, Rombauts W \& Claessens F (1999) Differential DNA binding by the androgen and glucocorticoid receptors involves the second $\mathrm{Zn}$-finger and a C-terminal extension of the DNA-binding domains. Biochemical Journal 341, 515-521.

Scholl TO, Hediger ML, Schall JI, Fischer RL \& Khoo CS (1993) Low zinc intake during pregnancy: its association with preterm and very preterm delivery. American Journal of Epidemiology 137, 1115-1124.

Scott BJ \& Bradwell AR (1983) Identification of the serum binding proteins for iron, zinc, cadmium, nickel and calcium. Clinical Chemistry 29, 629-633.

Scuderi P (1990) Differential effects of copper and zinc on human peripheral blood monocyte cytokine secretion. Cellular Immunology 126, 391-405.

Shimizu N, Yamauchi Y \& Aoki T (1999) Treatment and management of Wilson's disease. Pediatrics International 41, 419-422.

Simkin PA (1976) Oral zinc sulphate in rheumatoid arthritis. Lancet ii, $539-542$.

Skamoto A, Omirulleh S, Nakayama T \& Iwabuchi M (1996) A zinc-finger-type transcription factor WZF-1 that binds to a novel cis-acting element of histone gene promoters represses its own promoter. Plant and Cellular Physiology 37, 557-562.

Sohnle PG, Collins-Lech C \& Wiessner JH (1991) The zincreversible antimicrobial activity of neutrophil lysates and abscess fluid supernatants. Journal of Infectious Diseases 164, 137-142.

Song A, Chen YF, Thamatrakoln K, Storm TA \& Krensky AM (1999) RFLAT-1: a new zinc finger transcription factor that activates RANTES gene expression in T lymphocytes. Immunity 10, 93-103.

Sood SM, Wu MX, Hill KA \& Slattery CW (1999) Characterization of zinc-depleted alanyl-tRNA synthetase from Escherichia coli: role of zinc. Archives of Biochemistry and Biophysics $\mathbf{3 6 8}$, 380-384.

Sturniolo GC, Mestriner C, Irato P, Albergoni V, Longo G \& D'Inca R (1999) Zinc therapy increases duodenal concentrations 
of metallothionein and iron in Wilson's disease patients. American Journal of Gastroenterology 94, 334-338.

Sundström M, Abrahamsen L, Antonsson P, Mehindate K, Mourad W \& Dohlsten M (1996) The crystal structure of staphylococcal enterotoxin type $\mathrm{D}$ reveals $\mathrm{Zn}^{2+}$ mediated homodimerization. EMBO Journal 15, 6832-6840.

Tanaka Y, Shiozawa S, Morimoto I \& Fujita T (1989) Zinc inhibits pokeweed mitogen-induced development of immunoglobulinsecreting cells through augmentation of both CD4 and CD8 cells. International Journal of Immunopharmacology 11, 673-679.

Taylor GA \& Blackshear PJ (1995) Zinc inhibits turnover of labile mRNAs in intact cells. Journal of Cellular Physiology 162, 378-387.

The Finnish-German APECED Consortium (1997) An autoimmune disease, APECED, caused by mutations in a novel gene featuring two PHD-type zinc-finger domains. Autoimmune Polyendocrinopathy-Candidiasis-Ectodermal Dystrophy. Nature Genetics 17, 399-403.

Tierno PM Jr \& Hanna BA (1985) In vitro amplification of toxic shock syndrome toxin-1 by intravaginal devices. Contraception 31, 185-194.

Todd WK, Elvelym A \& Hart EB (1934) Zinc in the nutrition of the rat. American Journal of Physiology 107, 146-156.

Trubiani O, Antonucci A, Palka G \& Di-Primio R (1996) Programmed cell death of peripheral myeloid precursor cells in Down patients: effect of zinc therapy. Ultrastructural Pathology 20, 457-462.

Tsuda M, Imaizumi K, Katayama T, Kitagawa K, Wanaka A, Tohyama M \& Takagi T (1997) Expression of zinc transporter gene, $\mathrm{ZnT}-1$, is induced after transient forebrain ischemia in the gerbil. Journal of Neuroscience 17, 6678-6684.

Turk S, Bozfakioglu S, Ecder ST, Kahraman T, Gurel N, Erkoc, Aysuna N, Turkmen A, Bekiroglu N \& Ark E (1998) Effects of zinc supplementation on the immune system and on antibody response to multivalent influenza vaccine in hemodialysis patients. International Journal of Artificial Organs 21, 274-278.

Turner J \& Crossley M (1998) Cloning and characterization of $\mathrm{mCtBP} 2$, a co-repressor that associates with basic Kruppel-like factor and other mammalian transcriptional regulators. EMBO Journal 17, 5129-5140.

Umezawa K, Nakazawa K, Uchihata Y \& Otsuka M (1999) Screening for inducers of apoptosis in apoptosis-resistant human carcinoma cells. Advances in Enzyme Regulation 39, 145-156.

Valberg LS, Flanagan PR \& Chamberlain MJ (1984) Effect of iron, tin and copper on zinc absorption in humans. American Journal of Clinical Nutrition 40, 536-541.

Vallee BL \& Falchuk KH (1993) The biochemical basis of zinc physiology. Physiological Reviews 73, 79-118.

Varadinova TL, Bontchev PR, Nachev CK, Shishkov SA, Strachilov D, Paskalev Z, Toutekova A \& Panteva M (1993) Mode of action of $\mathrm{Zn}$-complexes on herpes simplex virus type 1 infection in vitro. Journal of Chemotherapy 5, 3-9.

Villiers MB, Gabert FM, Jacquier MR \& Colomb MG (1993) Involvement of the $\mathrm{Zn}$-binding region of the tetanus toxin in $\mathrm{B}$ and $\mathrm{T}$ recognition. Influence of $\mathrm{Zn}$ fixation. Molecular Immunology 30, 129-136.

Warner GL \& Lawrence DA (1986) Stimulation of murine lymphocyte response by cations. Cellullar Immunology 101, 425-439.
Weiss G, Wachter H \& Fuchs D (1995) Linkage of cell-mediated immunity to iron metabolism. Immunology Today 16, 495-500.

Weiss G, Widner B, Zoller H \& Fuchs D (1998) The immunobiology of zinc and the kidney. Immunology Today 19, 193.

Wellinghausen N, Driessen C \& Rink L (1996a) Stimulation of human peripheral blood mononuclear cells by zinc and related cations. Cytokine 18, 767-771.

Wellinghausen N, Fischer A, Kirchner H \& Rink L (1996b) Interaction of zinc ions with human peripheral blood mononuclear cells. Cellular Immunology 171, 255-261.

Wellinghausen N, Kern WV, Jöchle W \& Kern P (2000) Zinc serum level in human deficiency virus infected patients in relation to immunological status. Biological Trace Element Research 73, 79-89.

Wellinghausen N, Kirchner H \& Rink L (1997a) The immunobiology of zinc. Immunology Today 18, 519-521

Wellinghausen N, Martin M \& Rink L (1997b) Zinc inhibits IL-1 dependent $\mathrm{T}$ cell stimulation. European Journal of Immunology 27, 2529-2535.

Wellinghausen N, Schromm AB, Seydel U, Brandenburg K, Luhm J, Kirchner H \& Rink L (1996c) Zinc enhances lipopolysaccharide-induced monokine secretion by a fluidity change of lipopolysaccharide. Journal of Immunology 157, 3139-3145.

Williams AJ, Khachigian LM, Shows T \& Collins T (1995) Isolation and characterization of a novel zinc-finger protein with transcription repressor activity. Journal of Biological Chemistry 270, 22143-22152.

Worwag M, Classen HG \& Schumacher E (1999) Prevalence of magnesium and zinc in nursing home residents in Germany. Magnesium Research 12, 181-189.

Wright SD \& Kolesnick RN (1995) Does endotoxin stimulate cells by mimicking ceramide? Immunology Today 16, 297-302.

Yamagata K, Kaufmann WE, Lanahan A, Papapavlou M, Barnes CA, Andreasson KI \& Worley PF (1994) Egr3/Pilot, a zinc finger transcription factor, is rapidly regulated by activity in brain neurons and colocalizes with Egr1/zif268. Learning and Memory 1, 140-152.

Yang XW, Zhong R \& Heintz N (1996) Granule cell specification in the developing mouse brain as defined by expression of the zinc finger transcription factor RU49. Development 122, $555-566$.

Yuzbasiyan-Gurkan VA, Brewer GJ, Vander AJ, Guenter MJ \& Prasad AS (1989) Net renal tubular reabsorption of zinc in healthy man and impaired handling in sickle cell anemia. American Journal of Hematology 31, 87-90.

Zalewski PD \& Forbes IJ (1993) Intracellular zinc and the regulation of apoptosis. In Programmed Cell Death: The Cellular and Molecular Biology of Apoptosis, pp. 73-85 [M Laviri and D Watters, editors]. Melbourne: Harword Academic Press.

Ziegler EE, Serfass RE, Nelson SE, Figueroa-Colon R, Edwards BB, Houk RS \& Thompson JJ (1989) Effect of low zinc intake on absorption and excretion of zinc by infants studied with ${ }^{70} \mathrm{Zn}$ as extrinsic tag. Journal of Nutrition 119, 1647-1653.

Zoli A, Altomonte L, Caricchio R, Gaossi A, Mirone L, Ruffini MP \& Magaro M (1998) Serum zinc and copper in active rheumatoid arthritis: correlation with interleukin 1 beta and tumour necrosis factor alpha. Clinical Rheumatology 17, 378-382. 